\title{
Biocultural indicators to support locally led environmental management and monitoring
}

\author{
Bryant C. DeRoy $^{1,2}$, Chris T. Darimont ${ }^{1,2}$ and Christina N. Service ${ }^{1,2,3}$
}

\begin{abstract}
Environmental management (EM) requires indicators to inform objectives and monitor the impacts or efficacy of management practices. One common approach uses "functional ecological" indicators, which are typically species whose presence or abundance are tied to functional ecological processes, such as nutrient productivity and availability, trophic interactions, and habitat connectivity. In contrast, and used for millennia by Indigenous peoples, biocultural indicators are rooted in local values and placebased relationships between nature and people. In many landscapes today where Indigenous peoples are reasserting sovereignty and governance authority over natural resources, the functional ecological approach to indicator development does not capture fundamental values and ties to the natural world that have supported social-ecological systems over the long term. Accordingly, we argue that the development and use of biocultural indicators to shape, monitor, and evaluate the success of EM projects will be critical to achieving ecological and social sustainability today. We have provided a framework composed of criteria to be considered when selecting and applying meaningful and efficacious biocultural indicators among the diverse array of potential species and values. We used a case study from a region now referred to as coastal British Columbia, Canada, to show how the suggested application of functional ecological indicators by the provincial government created barriers to the development of meaningful cogovernance. We then explained how the Kitasoo/Xai'xais First Nation designed and implemented a bioculturally relevant suite of indicators in their own EM and monitoring processes. Drawing on our experiences there and both the biocultural and functional ecological literature, we proposed six generalizable criteria (culturally salient, inclusive, sensitive to impacts, supportive of place-based relationships, perceptible, and linked to human well-being) that can guide resource stewards and agencies in selecting locally relevant indicators to implement biocultural EM and monitor the performance of outcomes.
\end{abstract}

Key Words: biocultural approaches; environmental management; indicators; Indigenous; locally led; monitoring

\section{INTRODUCTION}

Differences among indicators used in environmental management (EM) and monitoring often represent the interests and dominant knowledge sources associated with the governance system from which they emerge. Among many approaches to carrying out EM, which employ different indicators used in setting management thresholds and measuring performance or outcomes, one dominant approach is the functional ecology approach. Drawing on Western science, and specifically population and community ecology, this reductionist approach seeks to maintain the linkages, processes, and interactions that make up an ecological system (Dufrêne and Legendre 1997, Roberge and Angelstam 2004). Indicators used in functional ecology approaches are typically representative of certain biogeoclimatic conditions, ecosystem characteristics, or ecological processes (Caro and O'Doherty 1999, Gilby et al. 2017). Indicator species are often selected according to criteria that can evaluate the roles that a given species plays within its community (Siddig et al. 2016). For example, woodpeckers (Picidae) have been shown to be reliable indicators of local bird richness, as well as the overall health of forest ecosystems, because they require large patches of mature forest and are habitat engineers for other species (Martin and Eadie 1999, Roberge and Angelstam 2004, Drever et al. 2008). However, there may be many different functional ecological indicator species for a given system.

In a functional ecology approach, a short list of indicator species is typically selected from the vast number of species that comprise a system to simplify management and monitoring efforts.
"Umbrella species" (Frankel and Soulé 1981, as cited in Roberge and Angelstam 2004) and groups of umbrella species are often used. "Focal species" (Lambeck 1997), also frequently used as indicators, are sensitive to environmental changes and have broadscale or varied habitat requirements that encompass the needs of many other species and trophic interactions in the system (Lambeck 1997, Roberge and Angelstam 2004). For example, in the Canadian Rocky Mountains, carnivores have been proposed as useful focal species in determining ecological thresholds for EM because their individual niche characteristics and collective habitat requirements encompass those of many other cooccurring species (Carroll et al. 2001). These and other focal species comprise a form of functional ecological indicator that is commonly used to determine conservation goals and help set thresholds for minimum habitat requirements and to monitor and evaluate EM outcomes (Noss 1990, 1999, Roberge and Angelstam 2004). Criteria that are often used to determine the suitability of functional ecological indicators include endemism, impact of habitat area or patch size on population viability (e.g., fecundity and survival), specificity of ecological processes that limit the distribution of individuals or populations, and conservation status (Lambeck 1997, Caro and O'Doherty 1999, Carignan and Villard 2002, Coppolillo et al. 2004).

Although offering a potentially useful approach to measure impacts of land use, the focus on functional ecological criteria and indicators, particularly when driven by centralized state governments, has prevented local uptake and success in EM scenarios around the world. Functional ecological indicators are

${ }^{1}$ Department of Geography, University of Victoria, Victoria, British Columbia, Canada, ${ }^{2}$ Raincoast Conservation Foundation, Bella Bella, British Columbia, Canada, ${ }^{3}$ Spirit Bear Research Foundation, Klemtu, British Columbia, Canada 
often developed by centralized management agencies (e.g., provincial, state, or federal governments) that have colonized or asserted decision-making authority over Indigenous territories, failed to accept guidance from local communities (Indigenous or non-Indigenous), and drawn on observational data that may not always be derived from the area affected by management decisions (Reed et al. 2006, Sterling et al. 2017a). Additionally, many consider that contemporary EM has not appropriately used scientific information in a way that fosters benefits to social, cultural, and economic needs while also conserving biodiversity (Slocombe 1993, 1998, Sutherland et al. 2004, Turner et al. 2008, Cook et al. 2010, 2012, Chan et al. 2012b, Pullin et al. 2013, Artelle et al. 2014). This is partly because of the omission of social and cultural values during the development of ecological indicators used in management and monitoring (Turner et al. 2008, Chan et al. 2012a, b, Sterling et al. 2017a).

In contrast to functional ecological approaches, biocultural approaches to EM projects, and their indicator development, typically start with values important to local governments, communities, and stakeholders. Measures are developed based on in situ values (Garibaldi and Turner 2004, Maffi 2005, Maffi and Woodley 2012, Cuerrier et al. 2015, Gavin et al. 2015, 2018, Biedenweg et al. 2017, Sterling et al. 2017a, Artelle et al. 2018, McCarter et al. 2018). For example, in the Western Province of the Solomon Islands a collaborative group of place-based researchers and community members are codeveloping sustainability and well-being indicators based on values, perceptions, and observations of community members resulting in indicators at various scales, e.g., habitat and species level (McCarter et al. 2018). Biocultural approaches to EM foster human well-being and ecosystem integrity at the subregional scale, both major components of modern EM and global sustainability goals (Millennium Ecosystem Assessment 2005, Mascarenhas et al. 2010, Gavin et al. 2015, 2018, Hausmann et al. 2016, Bennett et al. 2017, Biedenweg et al. 2017, Sterling et al. $2017 a, b)$. Emphasizing their relevance and potential for governance resurgence by Indigenous nations is the acknowledgment that biocultural approaches to EM have promoted social-ecological resilience for thousands of years (Berkes et al. 2000, Trosper 2002, Haggan et al. 2006, Atlas et al. 2017, Artelle et al. 2018). Despite this history, however, there is currently no overarching set of criteria to aid in the selection of biocultural indicators in today's complex resource management world, in which scientific approaches and tools are available and several governance arrangements often interact in managing the same landscapes, i.e., Indigenous, regional, state, federal, and international.

We offer a practical and flexible suite of criteria drawn from our experience working in Indigenous-led EM and supported by the literature on both biocultural and functional ecological approaches to indicator development that can steward desired outcomes in biocultural EM. We then show how biocultural indicators that exhibit these criteria can facilitate cross-cultural EM in complex geographies of coexistence (Howitt et al. 2013). As we detail subsequently, these indicators can communicate in situ management priorities and monitor and evaluate the implementation of EM. We develop this framework of criteria to help distill biocultural approaches to indicator development that foster socio-cultural resilience and well-being, while also promoting ecosystem integrity and biodiversity protection in the context of current resource extraction pressures. We illustrate these themes with a case study from Kitasoo/Xai'xais Territory in an area now also known as coastal British Columbia, Canada.

\section{CASE STUDY}

The nuances of environmental management implementation and cogovernance in the Great Bear Rainforest

The Great Bear Rainforest (GBR) of British Columbia, Canada, provides a model system to understand the value of applying biocultural approaches to promote socially, culturally, and ecologically sustainable outcomes in EM. The GBR is a complex geophysical landscape of archipelagos, fjords, and mountainous terrain with a diversity of ecosystems from the hypermaritime rain forests to the drier interior montane forests. The terrestrial and freshwater environments have been enriched with marinederived nutrients dispersed by terrestrial and avian consumers, as well as Indigenous peoples from pulses of Pacific salmon (Oncorhynchus spp.), Pacific herring (Clupea pallasii), and eulachon (Thaleichthys pacificus), among other marine species, for thousands of years (Gende et al. 2002, Brown and Brown 2009, Fox et al. 2014, Trant et al. 2016). The rich forested lands in the GBR are also considered to be a globally significant biodiversity refuge and a last remaining vestige of contiguous temperate old growth forest, valued for biodiversity, tourism, carbon storage, and commercial logging (DellaSala et al. 2011, Lertzman and Mackinnon 2014).

The geopolitical and social/cultural landscape of EM is also extremely complex. First Nations have continually occupied and actively stewarded terrestrial and marine systems in the GBR for millennia (Trosper 2002, Haggan et al. 2006, Brown and Brown 2009). Prior to European colonization, which brought smallpox epidemics and deliberate cultural genocide resulting in rapid depopulation, there were hundreds of villages and camps, seasonal and permanent, scattered along the coastline in the region (Cannon 2002). There is a rich diversity of language groups, with distinct cultural practices and lineages, composed of different clans (Beck 2000). Indigenous laws, hereditary leadership, and the potlatch system governed how, where, and by whom resources were used and stewarded (Trosper 2002, Brown and Brown 2009). Deeply rooted social and cultural ties to places, species, and interspecies relationships, as well as traditional governance systems, continue despite the impacts of colonialism (Brown and Brown 2009, Artelle et al. 2018). Although never surrendering their titles to the Crown, First Nations' land and seascapes in this region also occur within the asserted boundaries of the province of British Columbia and the nation of Canada. Ending decades of conflict regarding land use in these forests (namely, commercial logging), there has been recently legislated agreement among First Nations, the government of British Columbia, environmental nongovernmental organizations (ENGOs), and private-sector forest industry companies. However, the legal objectives established in the GBR (land use) order (hereafter LUO; British Columbia Ministry of Forests, Lands, and Natural Resource Operations 2016) remain decoupled from existing institutions and stewardship goals of some local communities. 
The process by which indicator species were developed illustrates this disconnect. During negotiations that led to the GBR LUO, the provincial government met with First Nations, industry groups, and ENGOs to select a suite of focal species that aimed to guide management targets to protect ecological integrity and biodiversity under the guiding principles of ecosystem-based management (EBM). The principles of EBM include maintaining viable populations of native species in their current range, including the diversity of native ecotypes in protected areas; maintaining the functioning of ecological processes across scales, e.g., nutrient cycles and disturbance regimes; setting management goals at appropriate timescales (longer term); and accounting for human use, interaction, and occupancy of these areas (Grumbine 1994, Price et al. 2009). The resultant focal species habitat models were developed to set landscape-scale management targets. As we explain next, these targets, however, did not adequately represent the fundamental values and processes of in situ First Nations' institutions (Price et al. 2009, Affolderbach et al. 2012).

Although the development of conservation targets in the GBR was officially a government-to-government negotiation between First Nations and the province of British Columbia, the balance of power was sometimes inequitable. For example, inequity was created when the province of British Columbia selected indicators that were outside of First Nations' local ecological knowledge (LEK) and Indigenous knowledge (IK). This put the two governments on very different playing fields in terms of what data they could contribute. Two such species were the Marbled Murrelet (Brachyramphus marmoratus) and the Northern Goshawk (Accipter gentilis). Both are threatened species that are associated with mature forests and large trees but are not commonly referenced in food, social, or ceremonial practices or cultural beliefs among First Nations in the region, aside from the Haida (Committee on the Status of Endangered Wildlife in Canada 2012). Although these threatened species are important ecologically, they did not resonate with First Nations' conservation priorities. Further discord was created when provincial biologists did not take into account LEK or IK in the habitat suitability models for other focal species that were culturally significant (see Service et al. [2014] for an example with grizzly bear [Ursus arctos] distributions). Many of these plans were never fully implemented because of the imbalance of knowledge sets between the province and First Nations that was created when purely functional ecological indicators were used. The only focal species that has since been fully included in the land use planning process is the grizzly bear, which is a touchstone of cultural significance for many First Nations in the region. First Nations could supply their own data sets for critical (class A and B) grizzly bear habitat, which improved the existing habitat maps developed by the team of provincial biologists and spatial analysts (Service et al. 2014). The opportunity for First Nations to provide their own data sets leveled the playing field in terms of information sharing, which facilitated cogovernance.

Other disparities and disconnects between decision makers are a product of an EM scenario that emphasizes economic factors, i.e., market viability of yield and productivity for future tree harvest, rather than social or cultural factors. Although the GBR LUO allows for the opportunity to incorporate cultural values into land and resource management, the regulations that make reference to schedules listing culturally significant values and species still place a higher legal protection for economic impacts. For example, "aboriginal heritage features," defined in the legislation as an "artefact, feature or site that is important to cultural practices, knowledge or heritage of a First Nation," may be altered or removed if it is "required for road access, other infrastructure, or to address a safety concern and there is no practicable alternative" (British Columbia Ministry of Forests, Lands, and Natural Resource Operations 2016:15, 26). More broadly, the chief forester at the Ministry of Forests, Lands and Natural Resource Operations still sets the allowable annual cut, i.e., the maximum total volume of wood extracted yearly, for each forest district in the region without requirement for direct or transparent negotiation with First Nations (British Columbia Ministry of Forests, Lands, and Natural Resource Operations 2016). Although by definition and colonial law there is a power asymmetry, in the current political climate some of these issues may be negotiated on a government-to-government basis However, the bias in language used in the GBR LUO toward economic factors and the agendas of centralized colonial governments can contribute to "knowledge disconnects" during implementation that prevent positive outcomes for sustainability and well-being in situ (Howitt et al. 2013, Sterling et al. 2017a, McCarter et al. 2018). Such disconnects have also been referred to as "intercultural capacity deficits," a lack of knowledge, understanding, or acceptance of cross-cultural values, institutions, and worldviews that prohibits intercultural communication and/or the performance of collaborative efforts (Allenby 2006, Turner et al. 2008, Howitt et al. 2013). Intercultural capacity deficits create a major barrier to success in cogoverned EM arrangements globally (Howitt et al. 2013).

Insights from the GBR can inform similar EM scenarios with overlapping governance structures and a diversity of worldviews. When the provincial agencies developed EM protocols, agendas, and resources that did not incorporate LEK or IK (Price et al. 2009, Service et al. 2014) or formalize support to protect longestablished ties between social and ecological systems, they disregarded existing EM structures that have been in place for thousands of years, e.g., the potlatch system (Trosper 2002, Turner et al. 2013, Artelle et al. 2018). Similar errors have occurred in many intercultural EM scenarios and are contributing to negative outcomes for biocultural resilience and biodiversity conservation globally (Maffi and Woodley 2012, Howitt et al. 2013, Cuerrier et al. 2015, Sterling et al. 2017a, McCarter et al. 2018).

\section{DISCUSSION}

\section{Lessons from the Great Bear Rainforest and beyond}

In British Columbia and abroad, some First Nations have developed or are developing values-led management plans to implement EM and bridge these gaps. Management plans provide a tool that enables in situ agencies to communicate goals and priorities across cultures to bridge knowledge disconnects. For example, in both Canada and New Zealand, First Nations have developed written management plans that are guided by Indigenous law and cultural values that have always governed stewardship practices in those territories (Borrows 2005, Artelle et al. 2018, Kitasoo/Xai'xais 2018). In some cases, these management plans are considered living documents that allow for 
continual development. The resurgence of values-led approaches to EM is helping to reinforce critical components of social and cultural well-being, such as relationships or connections to place (Artelle et al. 2018).

The Kitasoo/Xai'xais First Nation, among others, is implementing its own strategy for applying EM. Its goals are being developed by the community and contributing to broader goals outlined in the GBR LUO. For example, the Kitasoo/Xai'xais Stewardship Authority is conducting cultural feature inventories to learn more about the distribution and abundance of culturally significant values on the landscape in efforts to measure and mitigate impacts from forestry. The Kitasoo/Xai'xais Stewardship Authority models its program after the Haida Nation, which negotiated a different agreement with the province of British Columbia (Council of the Haida Nation 2013), to implement a biocultural approach focused on ground-based efforts to identify cultural and heritage values before they become impacted by forestry. The Kitasoo/Xai'xais Stewardship Authority has developed inventory methods and standards, inspired by those developed by the Haida Nation, to survey for and identify culturally significant values and species in addition to threatened or endangered species and ecosystems. This process on which it is embarking provides an opportunity to implement biocultural EM in the context of modern forestry and realize locally driven priorities on the ground. Drawing on our experience in this process and foundational concepts from the literature on both functional ecological and bicultural indicators, we next offer insight into designing appropriate indicators for biocultural monitoring, an important starting point for locally driven EM.

\section{Emergent criteria to evaluate the utility of biocultural indicators} To implement management plans and actualize their benefits, appropriate indices are required to guide objectives and measure outcomes. Biocultural indicators can offer a culturally relevant and comprehensive approach for communicating values and priorities across cultures to promote social, cultural, economic, and ecological resilience (Gavin et al. 2015, Sterling et al. 2017a). However, the process of defining appropriate biocultural indicators has not been extensively developed (Sterling et al. 2017a). There are many methods for developing indicators that involve community input, e.g., surveys, interviews, and focus groups; however, there are few resources available that can help guide this selection process to filter appropriate indicators. These criteria provide a way to distill locally relevant indicators and empower local communities to protect in situ values before they are damaged. Although the selection of biocultural indicators is necessarily place dependent, common themes can be derived from literature on biocultural diversity conservation. The set of criteria we propose in Figure 1 is intended to guide the selection process of indicators that represent local values, facilitate cross-scale linkages, and provide effective measures to evaluate biocultural EM outcomes.

To refine these themes into criteria, we used an inductive approach to identify the criteria in Figure 1, which emerged as foundational concepts from our experience working in Indigenous-led (in our case, the Kitasoo/Xai'xais First Nation) biocultural stewardship. These criteria reflect key concepts that enabled progress in a highly contentious and complex governance process. We acknowledge that these criteria emerged from our experience working with one
First Nation among thousands. We note that the process in other parts of the world where different governments have asserted competing claims on Indigenous peoples' lands and waters will likely be different, perhaps radically, than that experienced by the Kitasoo/Xai'xais First Nation. Complementing our personal interactions, which stem from many years working with and in the service of the Kitasoo/Xai'xais, we also searched the biocultural and functional ecological indicators literature to ascertain if (and if so, how) these concepts have been applied more broadly. We illustrate subsequently how all of these criteria reflect core components of an Indigenous EM paradigm in which the Kitasoo/Xai'xais also mobilized Western knowledge paradigms to implement biocultural EM.

Fig. 1. Six emergent criteria (culturally salient, supportive of place-based relationships, inclusive, sensitive to impacts, perceptible, and linked to human well-being) that can be considered in the development of biocultural indicators for use in environmental management and monitoring.

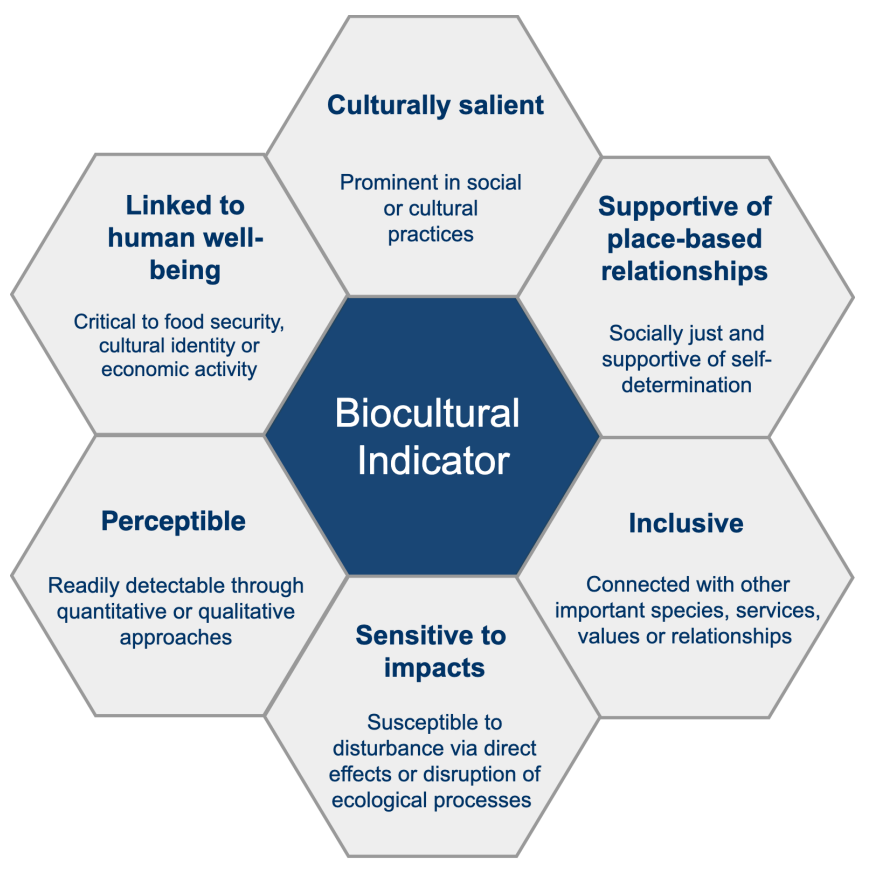

Biocultural EM is place based, and therefore, we offer these criteria as a synthesis of the concepts that enabled the implementation of biocultural EM in Kitasoo/Xai'xais Territory. However, we suggest their relevance as a tool to reduce conflict and guide collaborative conservation outcomes in other geographies of coexistence, particularly where Western science approaches to stewardship historically or currently overlap spatially with IK-based approaches. We recognize that purely IKbased EM approaches may differ widely from the approach taken by the Kitasoo/Xai'xais. It is also critical to recognize that a fundamental component of our case study is that it was Indigenous led. Knowledge integration has been and can be a damaging process when led by ex situ agencies because of the political nature of EM and power asymmetries (Nadasdy 1999, 2003). Ex situ agencies, e.g., colonial governments, have a history 
of ascribing unequal value to different knowledge sources or attempting to conform other knowledge sources to fit a Western science lens, which can further remove decision-making power from in situ agencies (Nadasdy 1999, Bohensky and Maru 2011). Therefore, it is paramount that context, politics, and decisionmaking power are deeply considered prior to developing biocultural indicators in-line with these criteria (Nadasdy 2003, Howlett et al. 2009, Takeda and Røpke 2010, Bohensky and Maru 2011, Moore and Tjornbo 2012). In Canada and other commonwealth nations, biocultural indicators developed in-line with these criteria may offer an opportunity for engagement around reconciliation if colonial government involvement is permitted by Indigenous nations and if the process is Indigenous led.

In the GBR, there was conflict from the start of negotiations because the process of developing indicators and conservation targets was led by ex situ agencies, i.e., the province of British Columbia, forestry companies, and ENGOs. Meanwhile, First Nations in the region were continuously monitoring other biocultural indicators, e.g., herring, salmon, eulachon, and grizzly bears. The example of the grizzly bear as being the only indicator species to be coimplemented successfully by First Nations and the province of British Columbia illustrates (1) how vital it was for conservation outcomes that the process was locally led and (2) how the following criteria could have guided the province (and other agencies) to engage in a manner that supported local priorities and existing institutions. With this in mind, the following criteria offer a means to communicate priorities between in situ and ex situ actors and outline how the process of indicator development can and should be locally led. The conceptual framework that these criteria create is not prescriptive or intended to be a step-by-step approach but instead is offered to provide conceptual guidance while recognizing that processes will develop differently in different territories. Robust biocultural indicators may fully realize all six criteria; however, it is likely that all six criteria will not apply everywhere. Because our criteria emerged from our case study, in which the Kitasoo/Xai'xais led a biocultural approach to EM that drew on both IK paradigms and Western science paradigms, some criteria may not be applicable in purely IK-driven biocultural EM. We also acknowledge that none of us are Indigenous and that our backgrounds are in Western science, which might bias our understanding of this complex governance environment. The criteria we have presented do not speak for any Indigenous nation but instead reflect themes that are clearly defined by the Kitasoo/ Xai'xais as priority values that guide their approach to EM and have been shown to improve EM and enable cogovernance when ex situ agencies are willing to accept them. Although this article and the criteria were born out of collaboration with the Kitasoo/ Xai'xais Stewardship Authority, we do not represent the Kitasoo/ Xai'xais Nation or any other First Nation.

\section{Cultural saliency}

Cultural saliency provides a necessary starting point to biocultural indicators. Such saliency is a common theme in biocultural diversity projects (Maffi and Woodley 2012) and is central to the concepts of cultural keystone species (Garibaldi and Turner 2004) and cultural keystone places (Cuerrier et al. 2015). Garibaldi and Turner (2004) and Cuerrier et al. (2015) define elements of cultural influence that may form the best available definition of cultural saliency. Those elements include the extent of use in food, social, symbolic, or ceremonial practices; use as a seasonal indicator; persistence in comparison to cultural change; and the resistance to substitution or replacement (Garibaldi and Turner 2004). An example of a culturally salient species in the GBR is the grizzly bear, a species that is entrenched in cultural practices for a number of coastal First Nations in British Columbia (Housty et al. 2014, Artelle et al. 2018). Practices such as stories and ceremony reinforce concepts of relatedness, respect, and reciprocity between humans and grizzly bears in these systems (Housty et al. 2014, Artelle et al. 2018). These practices strengthen social-ecological relationships and the resilience of human-bear systems (Clark and Slocombe 2009, Artelle et al. 2018).

\section{Supportive of place-based relationships}

Biocultural indicators should also protect features that establish provenance of occupation or use and protect values that reinforce place-based relationships, such as archaeological sites (Sterling et al. 2017a). Much land in the GBR, as well as other regions of the world, has never been formally ceded by Indigenous nations. Frequently, if a nation were to pursue land claims through the Canadian courts system, it needed extensive evidence of occupation or use. Archaeological sites such as culturally modified trees (e.g., Fig. 2), as well as middens, pictographs, petroglyphs, or habitation sites, and so forth, are often the only remaining visible/tangible evidence of human presence on the landscape above the soil surface (Oliver 2007, Earnshaw 2017). These physical markers may also indicate sacred or important places and spiritual or social-ecological interactions, which can contribute significantly to local identity and sense of place (Östlund et al. 2002, Stedman 2003, Oliver 2007, Harwood and Ruuska 2013, Cuerrier et al. 2015). Less tangible markers such as place-based names and stories may indicate a strong connection to place, which can also be sensitive to impacts from management practices (Kaltenborn 1998, Williams and Stewart 1998, Hausmann et al. 2016).

Fig. 2. Two healing culturally modified western redcedar (Thuja plicata) trees in Kitasoo/Xai'xais Territory with large rectangular bark strip scars.

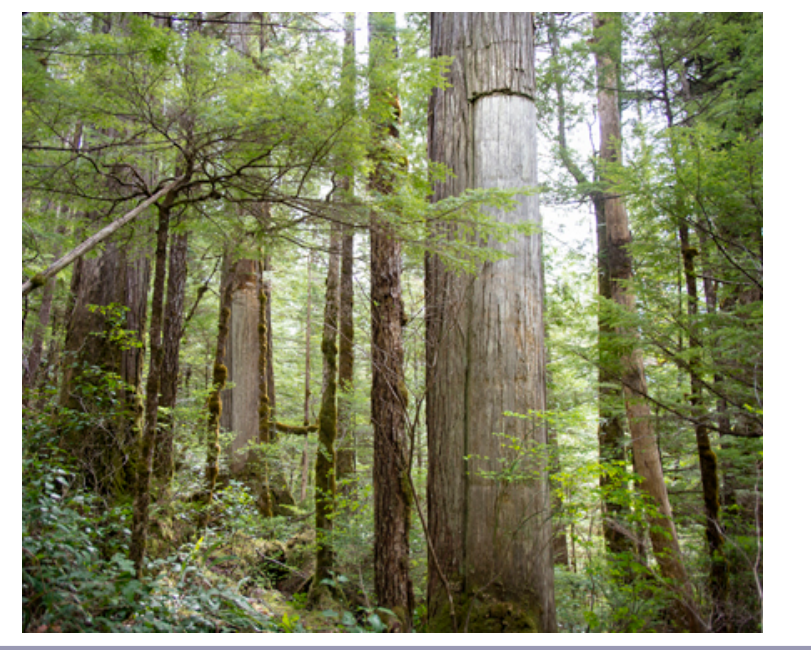




\section{Linked to human well-being}

Indicators should also have a strong positive impact on human well-being, which can often be linked to ecosystem health and the functioning of ecological processes (Sterling et al. 2017a). A positive impact on human well-being can be realized in many different forms (Chan et al. 2012a). For example, some indicators may foster connections to place or in other cases bring about financial or nutritional benefit. Species and values that both contribute to economic opportunities and are strongly linked to identity or cultural/spiritual fulfillment can be robust biocultural indicators. For example, seagrass (e.g., Zostera spp.) is considered to be a fundamental contributor to human well-being in coastal systems around the world because of the cultural services and ecosystem services various seagrass species provide (CullenUnsworth et al. 2014). By providing foundational habitat structure, seagrass meadows can be direct sources of food, medicine, or economic security and are strongly linked to a lifestyle or culture that is coupled to spiritual fulfillment (CullenUnsworth et al. 2014).

\section{Inclusive}

Biocultural indicators should also be inclusive, i.e., representative of a multitude of ecological and cultural values/relationships. Inclusiveness in the biocultural indicator development context encourages the colocation of content, e.g., critical ecosystem and cultural system components, with context, e.g., human relationships to place and ecological connectivity/integrity/ diversity (Dale and Beyeler 2001, Lertzman and Mackinnon 2014, Ens et al. 2016). Through promoting overlapping or intertwining values, inclusive biocultural indicators may compound the effectiveness of stewardship objectives and present more holistic measures of success (Gavin et. al 2015, Sterling et al. 2017b). This criterion not only builds on the idea of using umbrella species, but also incorporates less tangible components of socialecological systems. An example from the GBR of a species that is strongly inclusive is the western redcedar (Thuja plicata), which has been considered a cultural keystone species of Pacific Northwest First Peoples (Garibaldi and Turner 2004). Cultural uses of western redcedar trees require specific morphological characteristics, which are associated with different stand structures. For example, stands of trees that contain characteristics such as a large diameter, straight grain, and sound bole may be considered "monumental trees" that are suitable for cultural practices such as canoe building, totem carving, or mask carving (Council of the Haida Nation 2013, British Columbia Ministry of Forests, Lands, and Natural Resource Operations 2016, Sutherland et al. 2016, Benner et al. 2019). Because of the structural complexity in stands containing monumental cedar, these stands also provide valuable habitat for many other species, as well as gene and carbon stores (DellaSalla et al. 2011, Lertzman and Mackinnon 2014, Sutherland et al. 2016). In some cases, these stands may also contain culturally modified trees that provide archaeological evidence of historic occupation and land use in addition to a direct connection between community members alive today and their ancestors (Cuerrier et al. 2015, Earnshaw 2017, Benner et al. 2019). These characteristics of western redcedar make for an indicator that exemplifies the pairing of content (habitat and valuable materials) and context (cultural ties to place).

\section{Sensitive to impacts}

Indicators should be sensitive to management impacts. In other words, the biocultural indicator must be demonstrably affected by impacts to ecological processes that are directly linked to management practices (Lindenmeyer et al. 2000, Dale and Beyeler 2001, De Groot et al. 2010, Siddig et al. 2016). This requires that given biocultural indicators are strongly correlated or causal to specific ecological processes or that they themselves are the targets of extractive industries. In a best-case scenario, there would be little lag time between anthropogenic disturbance, e.g., land use practice or pollution, and perceptible effect (Dale and Beyeler 2001). This requires the appropriate matching of temporal and spatial scale between the selected indicator, potential impacts, and desired management goals (Niemi and McDonald 2004). A species that responds to impacts through a lagged effect on ecological processes because of a spatial or temporal mismatch may indicate a significant decline in ecosystem function only after it is too late to change management practices. For example, Marbled Murrelets on the central and north coast of British Columbia are not a robust EM indicator because it may exhibit heterogeneous nesting ecology in these mountainous regions, relying not only on old growth trees (subject to logging) but also cliffs and talus slopes (not at risk) for nesting locations (Barbaree et al. 2014). Additionally, murrelet habitat is partitioned between terrestrial nesting habitat and oceanic foraging habitat, which has made measuring impacts from terrestrial land management (e.g., nesting habitat loss and fragmentation) difficult to interpret, although it is clear that this species is impacted by cumulative effects (Committee on the Status of Endangered Wildlife in Canada 2012).

\section{Perceptible}

As the sociologist William Bruce Cameron (1963:13) reminded us, "Not everything that counts can be counted, and not everything that can be counted, counts." Some cultural values may be impossible to measure through the quantitative approaches of Western science, but this quality should not exclude them from monitoring efforts (Satterfield et al. 2013). Other approaches have long guided Indigenous peoples, and there is little reason why such long-held practices should cease (Berkes et al. 2000, Moller et al. 2004, Haggan et al. 2006, Ens et al. 2015, 2016, Waller and Reo 2018). Biocultural indicators can be measured through quantitative or qualitative approaches or a mixture of the two and draw from diverse methodologies. For instance, the collective long-term observations of the decline of Dungeness crabs (Cancer magister) by First Nations fishers in coastal British Columbia, as well as Indigenous-led empirical studies and the application of Indigenous law, led to closures of a commercial fishery and rapid recovery of Dungeness crabs in the region (Frid et al. 2016). Biocultural indicators should be relatively easy to monitor continuously or routinely over long periods of time (Dale and Beyeler 2001, De Groot et al. 2010). Despite being frequently chosen as umbrella species, rare or cryptic species may not be readily measurable and thus do not make robust biocultural EM indicators, unless there are reliable methods that have been developed to efficiently and accurately detect and monitor them. For example, eDNA (environmental DNA) is an emerging technology that may make surveying for some rare and cryptic species more feasible and reliable (see Mächler et al. [2014] for an example of rare macroinvertebrates). 
Perceptibility or measurability should also not be confined to estimates of abundance. For instance, quality or similar characteristics of indicators can be assessed over time. Eckert et al. (2018) described how Indigenous fishers experienced declines in the size of rockfish (Sebastes spp.) over several decades of commercial and recreational overexploitation in coastal British Columbia.

\section{CHALLENGES}

As EM planning and policy continue to adapt and change to facilitate sustainable outcomes for social-ecological systems, there remain major challenges to the implementation of these policies. As a result, many EM projects get stalled in the implementation stage, arguably the most important component of the EM process. Although each EM scenario is unique and requires a custom implementation plan, there are some common barriers that emerge in the literature and from our experience working in locally led EM. We outline subsequently some of these barriers and potential solutions to overcome these pressing challenges.

\section{Urgency matters}

The number of indicators required to adequately inform and monitor biocultural EM is place dependent and time dependent. Urgency increases as systems become more degraded (Dahl2012). There is added urgency to develop and implement biocultural indicators, which are underrepresented in sustainability indicators globally (Dahl 2012). In systems where management impacts have the potential to affect nonrenewable values, such as cultural heritage, there is a need for indicators that can be assessed rapidly and accurately to inform EM (United Nations Educational, Scientific, and Cultural Organization 2003, Cuerrier et al. 2015, Sterling et al. 2017a, McCarter et al. 2018). For example, a long history of commercial logging in coastal British Columbia that has targeted high-quality cedar has precipitated a decline of both monumental cedar and culturally modified trees (Guujaaw 1999, Turner et al. 2009, British Columbia Ministry of Natural Resource Operations and Ministry of Forests, Mines and Lands 2011, Earnshaw 2017, Benner et al. 2019).

\section{Different scales of time, space, and institutions matter}

In addition to the urgency in many systems, there is a need to understand better the local effects of longer term ecological processes that are a product of both local and global impacts. The impacts to some cultural values may be compounded by shortterm and longer term environmental change, as well as local and global drivers of change such as land use practices and pollution (Sterling et al. 2017a, McCarter et al. 2018). For example, yellowcedar (Cupressus nootkatensis), another culturally significant tree species, is a target of commercial logging because of its high market value; it is also susceptible to declines from climate change (Krapek and Buma 2015, Oakes et al. 2015, Oakes 2018). Concordantly, there is a need for indicators that provide information to inform EM and monitor long-term impacts. In some cases, one indicator may be able to achieve both goals (Dale and Beyeler 2001). Growing evidence suggests that by fostering a locally led or guided approach, robust biocultural indicators may provide a hub on which cross-scale linkages can be made and where in situ and ex situ agencies can engage to improve the outcomes of EM for social-ecological systems (Sterling et al. 2017a, McCarter et al. 2018).

\section{Resources available for monitoring}

Given that scale is a major factor in determining how different indicators may affect EM, there is value in categorizing issues that may be affected by changes at different rates. Given that monitoring is expensive, triage might be necessary. Additionally, threatened biocultural indicators may require resources for monitoring more immediately. For example, Pacific salmon are subject to cumulative effects from overharvesting, climate change, and terrestrial land use practices and have recently become a priority for increased monitoring resources in British Columbia (Price et al. 2008, 2017, Department of Fisheries and Oceans Canada 2019). One strategy is to build processes to monitor indicators that are already in place and have good baseline data. It is also much easier for local agencies to monitor species with which they are already engaged, e.g., taking fin clips for genetic stock assessment while harvesting salmon. However, long-term monitoring requires long-term financial and political commitments, which can be incongruous with short political cycles.

One solution to this wicked problem may be to look to and support Indigenous governance systems and institutions that have upheld long-term stewardship goals over millennia (Trosper 2002, Artelle et al. 2018). Systems such as hereditary leadership and the clan-based tenure system have long guided stewardship goals through the generations (Trosper 2002, Brown and Brown 2009, Salomon et al. 2015). Hereditary leaders are entrusted to placebased decision-making power for life to uphold Indigenous law and manage their allotted territories. This type of leadership is also evidence based, whereby leaders have to publicly demonstrate the continued productivity of their lands and waters or risk losing their title or rank (Trosper 2002, Salomon et al. 2015). This accountability to the public reinforces the values-driven management of resources for sustainable harvest (Trosper 2002, Brown and Brown 2009, Salomon et al. 2015). In the context of cogovernance, Gavin et al. (2015) also advocate for a focus on relationship building and partnerships to increase institutional diversity and capacity where the rights of all parties are fully understood, upheld, and respected. We suggest that if these approaches are locally led, then institutional diversity may also increase the resilience in these systems to waxing and waning support from short-term colonial (democratic) cycles of elections and governments.

\section{How many indicators?}

The number of indicators required to achieve desired outcomes in biocultural EM will vary as a function of system dynamics, scale, and project scope. All indicators that meet the aforementioned criteria should be considered in biocultural EM. However, fewer indicators that are highly inclusive and can capture the fundamental interactions, from drivers of change to impacts on biocultural values, may be more effective than many indicators with narrow scope (Landres et al. 1988, Levett 1998, Hagan and Whitman 2006, Tallis et al. 2010). Fewer are generally better; every new indicator brings the need to measure and monitor, which can be costly and time consuming. Prohibitive complexity can become an implementation issue if there are too many indicators to monitor (Tallis et al. 2010).

Considering that fewer highly inclusive indicators may facilitate desired outcomes in EM better than many less inclusive indicators, 
it could be argued, especially if monitoring resources are constraining, that indicators with strong links to cascading effects should be given priority. Cascading effects not only alter complex trophic interactions but also deeply impact local communities. For example, both the initial collapse of sea otters (Enhydra lutris) because of overharvest from the fur trade on the Pacific Coast and the subsequent reintroduction of sea otters, in conjunction with colonial mismanagement of shellfish fisheries, into areas where they were extirpated have caused negative impacts to Indigenous communities (Estes and Palmisano 1974, Salomon et al. 2015). Such linkages and indirect effects can be extremely difficult to manage. However, shifting toward precautionary management practices guided by biocultural indicators in industries that have known impacts on socially and culturally significant species and relationships, e.g., reducing the high percentage of bycatch of eulachon in the shrimp (Pandalus spp.) trawl fishery, could be one strategy to mitigate these less visible impacts. Supporting resurgent management practices, in some cases that are based on reciprocity, could be another strategy to build resilience in complex social-ecological systems (Salomon et al. 2015, Artelle et al. 2018).

\section{A ROBUST BIOCULTURAL INDICATOR}

\section{Sense of place}

One example of a biocultural indicator that can satisfy all six of the criteria is sense of place. Sense of place can be a vital component of cultural identity and well-being, as well as an encompassing indicator of social or cultural resilience for placebased cultures (Cheng et al. 2003, Bennett et al. 2017). Sense of place is built on the perceptions of in situ peoples, and therefore, numerous methodologies exist to evaluate those perceptions. For example, qualitative methods and Indigenous methodologies offer approaches to incorporate such seemingly intangible indicators in EM. Where the standard functional ecological tool kit may guide managers to focus on quantitative measures of biomass or a rare ecotype to set management targets, the evaluation of local peoples' perceptions can accurately assess the impacts that a given activity has on peoples' sense of place (Stedman 2003, Rogan et al. 2005, Fry et al. 2009, Bennett 2016, Caillon et al. 2017). In a cogovernance or Indigenous-led land use decision-making process, evaluating and respecting the perceptions of local people can be a method to prevent desecration of culturally salient spaces and place-based relationships and can provide an opportunity to strengthen relationships among communities, governments, and industry operators (Sterling et al. 2017a). Sense of place can be a highly inclusive indicator, encapsulating both social and cultural values/ relationships, as well as habitat and ecological relationships (Cheng et al. 2003). Considering how sense of place performs when evaluated against the six criteria, i.e., culturally salient, supportive of place-based relationships, inclusive, sensitive to impacts, perceptible, and linked to human well-being, it has the potential to be a robust biocultural indicator.

In addition to likely encapsulating the six criteria, sense of place can also illustrate how the criteria may be flexible for a variety of methodologies and ways of knowing. Perceptions, with a special focus on how they can monitor change over time as a function of proposed or tangible changes to the environment, can identify precautionary thresholds for sense of place, as well as other biocultural indicators, or inform management action in relation to longer term processes for which other data sources are lacking, such as climate change (Johannes 1998, Moller et al. 2004, Leonard et al. 2013, Sterling et al. 2017a). Apart from the perceptions of local peoples, there are other methods of monitoring change or impacts to sense of place. For example, analytical tools and observational data may help identify, define, reinforce, and communicate the boundaries of finer scale culturally significant areas that may or may not be currently known to local communities. For example, if historical evidence of occupation and resource use is a value important to a First Nations community, then culturally modified trees and groups of culturally modified trees may themselves constitute culturally salient spaces (e.g., Fig. 2; Harwood and Ruuska 2013, Cuerrier et al. 2015, Earnshaw 2017). Other methods such as "values mapping" can communicate existing relationships between people and place (McLain et al.2013). Participatory approaches to values mapping have been used to identify and define "special places" for consideration in resource management decision making on the Olympic Peninsula in Washington State (Cerveny et al. 2017). These examples show a variety of approaches to monitoring sense of place; we suggest that a key factor in the success of these approaches and others is that the process is locally led.

In addition to accommodating different methodologies and ways of knowing, sense of place can further illustrate how challenges of scale can be considered and ideally overcome. For example, in cultural landscapes there may be cultural keystone places at a variety of scales, e.g., important mountains, valleys, bays, estuaries, caves, stands/groves, village sites, individual petroglyphs, or trees. In some cases, these places can be cumulative, i.e., the sum of nearby places and the space in between can contribute to a sense of place (Cuerrier et al. 2015, Lepofsky et al. 2017). For example, the Whanganui River in New Zealand plays an important role in the culture of various Mâori groups and was recently attributed legal status to personhood by the parliamentary government of New Zealand (Parliamentary Counsel Office, New Zealand Legislation 2016). The legal designation attributes personhood not only to the river itself, but also as "an indivisible and living whole, comprising the Whanganui River from the mountains to the sea, incorporating all its physical and metaphysical elements" (Parliamentary Counsel Office, New Zealand Legislation 2016, section 1.2, as cited in Caillon et al. 2017). Sense of place can be multifaceted, incorporating a variety of different typologies of values, e.g., biological, recreational, historical, future, spiritual, aesthetic, economic, and cultural, among others, or defined by one key value (Brown and Reed 2000, Cerveny et al. 2017). This flexibility enables a custom and local approach to address the relevant priorities of communities in biocultural EM.

\section{LIMITATIONS}

The goal of our synthesis was to bring together key themes that have emerged during our collective years working in locally led and Indigenous-led EM. We used an inductive approach because many of the six criteria we have presented have been clearly defined and used by some First Nations in the area now referred to as the GBR. These criteria took shape through Indigenous laws and EM and monitoring practice, e.g., management plans and applied stewardship. Although the criteria we have presented emerged from our experience working with one First Nation 
among thousands globally, we have demonstrated how these criteria are flexible enough to apply outside of the GBR. Indeed, the criteria we offer also align with those detected in our informal review of related biocultural and functional ecology EM literature. We note, however, that each EM scenario should be treated as unique and that other locally led or Indigenous-led approaches may seek to develop their own criteria and indicators based on their own terms.

\section{CONCLUSION}

Increasing global resource demands create new challenges in designing management approaches that can provide sustainable and socially just outcomes in EM. One aspect that can address some problems that are common in cogovernance or resurgent EM arrangements is to support the development of indicators that acknowledge, represent, and uphold local values and relationships to the land. Applying a biocultural approach to indicator selection in cross-cultural EM provides a more inclusive option for stewarding both biological and socio-cultural diversity in comparison with purely ecological indicators and can bridge knowledge gaps in intercultural EM systems to facilitate cogovernance (Maffi 2005, Howitt et al. 2013, Service et al. 2014, Sterling et al. 2017a,b). By proposing a suite of six potential criteria that emerged from our case study and are supported by a diverse body of literature, we suggest characteristics that contribute to the utility and effectiveness of potential indicators in highly complex social-ecological systems. The set of criteria we developed may offer a tool to distill and communicate local priorities and promote stewardship outcomes that support biocultural resilience. These criteria should be considered a starting point for discourse around developing locally relevant indicators in a wide range of cross-cultural governance scenarios.

Responses to this article can be read online at: http://www.ecologyandsociety.org/issues/responses. $\mathrm{php} / 11120$

\section{Acknowledgments:}

We thank the Kitasoo/Xai'xais Stewardship Authority and Evan Loveless for comments on this manuscript. We also acknowledge and thank Douglas Neasloss, Vernon Brown (project co-lead), Rosie Child, and Andra Forney who were involved in developing the Kitasoo/Xai'xais biocultural inventory and monitoring program, which was the inspiration for many of the ideas presented in this paper. We also would like to acknowledge and thank our colleagues in the field: Santana Edgar, Chantal Pronteau, Stephen Neasloss, John May, Mitch Robinson, Sarein Basi-Primeau, and Sam Harrison. Additionally, we thank members of the Applied Conservation Science Lab at the University of Victoria for their support during the development of this manuscript. B. C. DeRoy was supported financially by a Raincoast Conservation Foundation Graduate Fellowship, C. T. Darimont by Natural Sciences and Engineering Research Council of Canada (NSERC) Discovery Grant (435683), and C. N. Service by the NSERC Vanier Fellowship and a Mitacs Accelerate Fellowship. We also thank the anonymous reviewers who considerably improved this manuscript.

\section{LITERATURE CITED}

Affolderbach, J., R. A. Clapp, and R. Hayter. 2012. Environmental bargaining and boundary organizations: remapping British Columbia's Great Bear Rainforest. Annals of the Association of American Geographers 102(6):1391-1408. https://doi.org/10.1080/00045608.2012.706567

Allenby, B. 2006. Macroethical systems and sustainability science. Sustainability Science 1(1):7-13. https://doi.org/10.1007/ s11625-006-0003-8

Artelle, K. A., J. D. Reynolds, P. C. Paquet, and C. T. Darimont. 2014. When science-based management isn't. Science 343 (6177):1311. https://doi.org/10.1126/science.343.6177.1311-a

Artelle, K. A., J. Stephenson, C. Bragg, J. A. Housty, W. G. Housty, M. Kawharu, and N. J. Turner. 2018. Values-led management: the guidance of place-based values in environmental relationships of the past, present, and future. Ecology and Society 23(3):35. https:// doi.org/10.5751/ES-10357-230335

Atlas, W. I., W. G. Housty, A. Béliveau, B. DeRoy, G. Callegari, M. Reid, and J. W. Moore. 2017. Ancient fish weir technology for modern stewardship: lessons from community-based salmon monitoring. Ecosystem Health and Sustainability 3(6):1341284. https://doi.org/10.1080/20964129.2017.1341284

Barbaree, B. A., S. K. Nelson, B. D. Dugger, D. D. Roby, H. R. Carter, D. L. Whitworth, and S. H. Newman. 2014. Nesting ecology of Marbled Murrelets at a remote mainland fjord in southeast Alaska. Condor 116(2):173-183. https://doi.org/10.1650/ CONDOR-13-116.1

Beck, D. 2000. Grammatical convergence and the genesis of diversity in the Northwest Coast Sprachbund. Anthropological Linguistics 42(2):147-213.

Benner, J., A. Knudby, J. Nielsen, M. Krawchuk, and K. Lertzman.2019. Combining data from field surveys and archaeological records to predict the distribution of culturally important trees. Diversity and Distributions 25(9):1375-1387. https://doi.org/10.1111/ddi.12947

Bennett, N. J. 2016. Using perceptions as evidence to improve conservation and environmental management. Conservation Biology 30(3):582-592. https://doi.org/10.1111/cobi.12681

Bennett, N. J., R. Roth, S. C. Klain, K. Chan, P. Christie, D. A. Clark, G. Cullman, D. Curran, T. J. Durbin, G. Epstein, A. Greenberg, M. P. Nelson, J. Sandlos, R. Stedman, T. L. Teel, R. Thomas, D. Veríssimo, and C. Wyborn. 2017. Conservation social science: understanding and integrating human dimensions to improve conservation. Biological Conservation 205:93-108. https://doi.org/10.1016/j.biocon.2016.10.006

Berkes, F., J. Colding, and C. Folke. 2000. Rediscovery of traditional ecological knowledge as adaptive management. Ecological Applications 10(5):1251-1262. https://doi.org/10.1890/1051-0761 (2000)010[1251:ROTEKA]2.0.CO;2

Biedenweg, K., H. Harguth, and K. Stiles. 2017. The science and politics of human well-being: a case study in cocreating indicators for Puget Sound restoration. Ecology and Society 22(3):11. https:// doi.org/10.5751/ES-09424-220311 
Bohensky, E., and Y. Maru. 2011. Indigenous knowledge, science, and resilience: what have we learned from a decade of international literature on "integration"? Ecology and Society 16 (4):6. https://doi.org/10.5751/ES-04342-160406

Borrows, J., 2005. Indigenous legal traditions in Canada. Washington University Journal of Law and Policy 19:167-223.

British Columbia Ministry of Forests, Lands, and Natural Resource Operations. 2016. Great Bear Rainforest order. British Columbia Ministry of Forests, Lands, and Natural Resource Operations, Victoria, British Columbia, Canada. [online] URL: https://www2.gov.bc.ca/assets/gov/farming-natural-resources-andindustry/forestry/timber-pricing/coast-timber-pricing/maps-andgraphics/great bear_rainforest_order___jan_21_2016.pdf

British Columbia Ministry of Natural Resource Operations and Ministry of Forests, Mines and Lands. 2011. Summary of cedar management considerations for coastal British Columbia. British Columbia Ministry of Natural Resource Operations and Ministry of Forests, Mines and Lands, Victoria, British Columbia, Canada. [online] URL: https://www.for.gov.bc.ca/rco/stewardship/ crit/docs/Coast\%20Cedar\%20Discusion\%20Paper\%2018Mar2011. pdf

Brown, F., and Y. K. Brown. 2009. Staying the course, staying alive - coastal First Nations fundamental truths: biodiversity, stewardship and sustainability. Biodiversity BC, Victoria, British Columbia, Canada. [online] URL: http://www.biodiversitybc. org/assets/Default/BBC_Staying_the_Course_Web.pdf

Brown, G., and P. Reed. 2000. Validation of a forest values typology for use in national forest planning. Forest Science 46 (2):240-247.

Caillon, S., G. Cullman, B. Verschuuren, and E. J. Sterling. 2017. Moving beyond the human-nature dichotomy through biocultural approaches: including ecological well-being in resilience indicators. Ecology and Society 22(4):27. https://doi. org/10.5751/ES-09746-220427

Cameron, W. B. 1963. Informal sociology: a casual introduction to sociological thinking. Random House, New York, New York, USA.

Cannon, A. 2002. Sacred power and seasonal settlement on the central Northwest Coast. Pages 311-338 in B. Fitzhugh and J. Habu, editors. Beyond foraging and collecting. Springer, Boston, Massachusetts, USA. https://doi.org/10.1007/978-1-4615-0543-3 13

Carignan, V., and M.-A. Villard. 2002. Selecting indicator species to monitor ecological integrity: a review. Environmental Monitoring and Assessment 78(1):45-61. https://doi.org/10.1023/ $\underline{\mathrm{A}: 1016136723584}$

Caro, T. M., and G. O'Doherty. 1999. On the use of surrogate species in conservation biology. Conservation Biology 13 (4):805-814. https://doi.org/10.1046/j.1523-1739.1999.98338.x

Carroll, C., R. F. Noss, and P. C. Paquet. 2001. Carnivores as focal species for conservation planning in the Rocky Mountain region. Ecological Applications 11(4):961-980. https://doi.org/10.1890/1051-0761 (2001)011[0961:CAFSFC]2.0.CO;2

Cerveny, L. K., K. Biedenweg, and R. McLain. 2017. Mapping meaningful places on Washington's Olympic Peninsula: toward a deeper understanding of landscape values. Environmental Management 60(4):643-664. https://doi.org/10.1007/s00267-017-0900$\underline{\mathrm{X}}$

Chan, K. M. A., A. D. Guerry, P. Balvanera, S. Klain, T. Satterfield, X. Basurto, A. Bostrom, R. Chuenpagdee, R. Gould, B. S. Halpern, N. Hannahs, J. Levine, B. Norton, M. Ruckelshaus, R. Russell, J. Tam, and U. Woodside. 2012a. Where are cultural and social in ecosystem services? A framework for constructive engagement. BioScience 62(8):744-756. https://doi.org/10.1525/ bio.2012.62.8.7

Chan, K. M. A., T. Satterfield, and J. Goldstein. $2012 b$. Rethinking ecosystem services to better address and navigate cultural values. Ecological Economics 74:8-18. https://doi. org/10.1016/j.ecolecon.2011.11.011

Cheng, A. S., L. E. Kruger, and S. E. Daniels. 2003. "Place" as an integrating concept in natural resource politics: propositions for a social science research agenda. Society \& Natural Resources 16(2):87-104. https://doi.org/10.1080/08941920309199

Clark, D. A., and D. S. Slocombe. 2009. Respect for grizzly bears: an aboriginal approach for co-existence and resilience. Ecology and Society 14(1):42. https://doi.org/10.5751/es-02892-140142

Committee on the Status of Endangered Wildlife in Canada (COSEWIC). 2012. COSEWIC assessment and status report on the Marbled Murrelet Brachyramphus marmoratus in Canada. COSEWIC, Ottawa, Ontario, Canada. [online] URL: https:// www.canada.ca/en/environment-climate-change/services/speciesrisk-public-registry/cosewic-assessments-status-reports/marbledmurrelet-2012.html

Cook, C. N., R. W. (Bill) Carter, R. A. Fuller, and M. Hockings. 2012. Managers consider multiple lines of evidence important for biodiversity management decisions. Journal of Environmental Management 113:341-346. https://doi.org/10.1016/j.jenvman.2012.09.002

Cook, C. N., M. Hockings, and R. W. (Bill) Carter. 2010. Conservation in the dark? The information used to support management decisions. Frontiers in Ecology and the Environment 8(4):181-186. https://doi.org/10.1890/090020

Coppolillo, P., H. Gomez, F. Maisels, and R. Wallace. 2004. Selection criteria for suites of landscape species as a basis for sitebased conservation. Biological Conservation 115(3):419-430. https://doi.org/10.1016/S0006-3207(03)00159-9

Council of the Haida Nation. 2013. Cultural feature identification standards manual. Council of the Haida Nation, Old Massett, Haida Gwaii, British Columbia, Canada. [online] URL: http:// www.haidanation.ca/wp-content/uploads/2017/03/

CFIC Standards Manual V3.pdf

Cuerrier, A., N. J. Turner, T. C. Gomes, A. Garibaldi, and A. Downing. 2015. Cultural keystone places: conservation and restoration in cultural landscapes. Journal of Ethnobiology 35 (3):427-448. https://doi.org/10.2993/0278-0771-35.3.427

Cullen-Unsworth, L. C., L. M. Nordlund, J. Paddock, S. Baker, L. J. McKenzie, and R. K. F. Unsworth. 2014. Seagrass meadows globally as a coupled social-ecological system: implications for human wellbeing. Marine Pollution Bulletin 83(2):387-397. https://doi.org/10.1016/j.marpolbul.2013.06.001 
Dahl, A. L. 2012. Achievements and gaps in indicators for sustainability. Ecological Indicators 17:14-19. https://doi. org/10.1016/j.ecolind.2011.04.032

Dale, V. H., and S. C. Beyeler. 2001. Challenges in the development and use of ecological indicators. Ecological Indicators 1(1):3-10. https://doi.org/10.1016/S1470-160X(01)00003-6

De Groot, R. S., R. Alkemade, L. Braat, L. Hein, and L. Willemen. 2010. Challenges in integrating the concept of ecosystem services and values in landscape planning, management and decision making. Ecological Complexity 7(3):260-272. https://doi. org/10.1016/j.ecocom.2009.10.006

DellaSala, D. A., F. Moola, P. Alaback, P. C. Paquet, J. W. Schoen, and R. F. Noss. 2011. Temperate and boreal rainforests of the Pacific Coast of North America. Pages 42-81 in Temperate and boreal rainforests of the world: ecology and conservation. Island, Washington, D.C., USA. https://doi.org/10.5822/978-1-61091-008-8_2

Department of Fisheries and Oceans Canada. 2019. British Columbia salmon and restoration innovation fund. Department of Fisheries and Oceans Canada, Ottawa, Ontario, Canada. [online] URL: http://www.dfo-mpo.gc.ca/fm-gp/initiatives/fishfund-bc-fonds-peche-cb/index-eng.html

Drever, M. C., K. E. H. Aitken, A. R. Norris, and K. Martin. 2008. Woodpeckers as reliable indicators of bird richness, forest health and harvest. Biological Conservation 141(3):624-634. https://doi.org/10.1016/j.biocon.2007.12.004

Dufrêne, M., and P. Legendre. 1997. Species assemblages and indicator species: the need for a flexible asymmetrical approach. Ecological Monographs 67(3):345-366. https://doi.org/10.1890/0012-9615 (1997)067[0345:SAAIST]2.0.CO;2

Earnshaw, J. 2017. "The trees you do not need ...": culturally modified forests and the Tsilhqot'in ruling. Midden 47(3):2-11.

Eckert, L. E., N. C. Ban, A. Frid, and M. McGreer. 2018. Diving back in time: extending historical baselines for yelloweye rockfish with Indigenous knowledge. Aquatic Conservation: Marine and Freshwater Ecosystems 28(1):158-166. https://doi.org/10.1002/ aqc. 2834

Ens, E. J., P. Pert, P. A. Clarke, M. Budden, L. Clubb, B. Doran, C. Douras, J. Gaikwad, B. Gott, S. Leonard, J. Locke, J. Packer, G. Turpin, and S. Wason. 2015. Indigenous biocultural knowledge in ecosystem science and management: review and insight from Australia. Biological Conservation 181:133-149. https://doi. org/10.1016/j.biocon.2014.11.008

Ens, E., M. L. Scott, Y. M. Rangers, C. Moritz, and R. Pirzl. 2016. Putting Indigenous conservation policy into practice delivers biodiversity and cultural benefits. Biodiversity and Conservation 25(14):2889-2906. https://doi.org/10.1007/s10531-016-1207-6

Estes, J. A., and J. F. Palmisano. 1974. Sea otters: their role in structuring nearshore communities. Science 185(4156):1058-1060. https://doi.org/10.1126/science.185.4156.1058

Fox, C. H., R. El-Sabaawi, P. C. Paquet, and T. E. Reimchen. 2014. Pacific herring Clupea pallasii and wrack macrophytes subsidize semi-terrestrial detritivores. Marine Ecology Progress Series 495:49-64. https://doi.org/10.3354/meps10588
Frankel, O., and M. E. Soulé. 1981. Conservation and evolution. Cambridge University Press, Cambridge, UK.

Frid, A., M. McGreer, and A. Stevenson. 2016. Rapid recovery of Dungeness crab within spatial fishery closures declared under Indigenous law in British Columbia. Global Ecology and Conservation 6:48-57. https://doi.org/10.1016/j.gecco.2016.01.002

Fry, G., M. S. Tveit, Å. Ode, and M. D. Velarde. 2009. The ecology of visual landscapes: exploring the conceptual common ground of visual and ecological landscape indicators. Ecological Indicators 9(5):933-947. https://doi.org/10.1016/j.ecolind.2008.11.008

Garibaldi, A., and N. Turner. 2004. Cultural keystone species: implications for ecological conservation and restoration. Ecology and Society 9(3):1. https://doi.org/10.5751/es-00669-090301

Gavin, M. C., J. McCarter, F. Berkes, A. T. P. Mead, E. J. Sterling, R. Tang, and N. J. Turner. 2018. Effective biodiversity conservation requires dynamic, pluralistic, partnership-based approaches. Sustainability 10(6):1846. https://doi.org/10.3390/ su10061846

Gavin, M. C., J. McCarter, A. Mead, F. Berkes, J. R. Stepp, D. Peterson, and R. Tang, 2015. Defining biocultural approaches to conservation. Trends in Ecology \& Evolution 30(3):140-145. https://doi.org/10.1016/j.tree.2014.12.005

Gende, S. M., R. T. Edwards, M. F. Willson, and M. S. Wipfli. 2002. Pacific salmon in aquatic and terrestrial ecosystems: Pacific salmon subsidize freshwater and terrestrial ecosystems through several pathways, which generates unique management and conservation issues but also provides valuable research opportunities. BioScience 52(10):917-928. https://doi. org/10.1641/0006-3568(2002)052[0917:PSIAAT]2.0.CO;2

Gilby, B. L., A. D. Olds, R. M. Connolly, N. A. Yabsley, P. S Maxwell, I. R. Tibbetts, D. S. Schoeman, and T. A. Schlacher. 2017. Umbrellas can work under water: using threatened species as indicator and management surrogates can improve coastal conservation. Estuarine, Coastal and Shelf Science 199:132-140. https://doi.org/10.1016/j.ecss.2017.10.003

Grumbine, R. E. 1994. What is ecosystem management? Conservation Biology 8(1):27-38. https://doi.org/10.1046/ j.1523-1739.1994.08010027.x

Guujaaw. 1999. The sacred workplaces of our ancestors. Pages 45-48 in G. G. Wiggins, editor. Proceedings of the Cedar Symposium: growing western redcedar and yellow-cypress on the Queen Charlotte Islands/Haida Gwaii (Queen Charlotte Islands/ Haida Gwaii, British Columbia, Canada, 28-30 May 1996). Province of British Columbia, Victoria, British Columbia, Canada. [online] URL: https://www.for.gov.bc.ca/hfd/pubs/docs/ mr/Mr094/Mr094-1.pdf

Hagan, J. M., and A. A. Whitman. 2006. Biodiversity indicators for sustainable forestry: simplifying complexity. Journal of Forestry 104(4):203-210.

Haggan, N., N. Turner, J. Carpenter, J. T. Jones, Q. Mackie, and C. Menzies. 2006. 12,000+ years of change: linking traditional and modern ecosystem science in the Pacific Northwest. UBC Fisheries Centre Working Paper 2006-02. Fisheries Centre, University of 
British Columbia, Vancouver, British Columbia, Canada. [online] URL: http://www.fisheries.ubc.ca/publications/working/2006/2006-02. pdf

Harwood, C., and A. K. Ruuska. 2013. The personhood of trees: living artifacts in the Upper Peninsula of Michigan. Time and Mind: The Journal of Archaeology, Consciousness and Culture 6 (2):135-157. https://doi.org/10.2752/175169713X13589680081812

Hausmann, A., R. Slotow, J. K. Burns, and E. D. Minin. 2016. The ecosystem service of sense of place: benefits for human wellbeing and biodiversity conservation. Environmental Conservation 43(2):117-127. https://doi.org/10.1017/S0376892915000314

Housty, W. G., A. Noson, G. W. Scoville, J. Boulanger, R. M. Jeo, C. T. Darimont, and C. E. Filardi. 2014. Grizzly bear monitoring by the Heiltsuk people as a crucible for First Nation conservation practice. Ecology and Society 19(2):70. https://doi.org/10.5751/ ES-06668-190270

Howitt, R., K. Doohan, S. Suchet-Pearson, S. Cross, R. Lawrence, G. J. Lunkapis, S. Muller, S. Prout, and S. Veland. 2013. Intercultural capacity deficits: contested geographies of coexistence in natural resource management. Asia Pacific Viewpoint 54(2):126-140. https://doi.org/10.1111/apv.12014

Howlett, M., J. Rayner, and C. Tollefson. 2009. From government to governance in forest planning? Lessons from the case of the British Columbia Great Bear Rainforest initiative. Forest Policy and Economics 11(5-6):383-391. https://doi.org/10.1016/j. forpol.2009.01.003

Johannes, R. E. 1998. The case for data-less marine resource management: examples from tropical nearshore finfisheries. Trends in Ecology \& Evolution 13:243-246. https://doi. org/10.1016/S0169-5347(98)01384-6

Kaltenborn, B. P. 1998. Effects of sense of place on responses to environmental impacts: a study among residents in Svalbard in the Norwegian high Arctic. Applied Geography 18(2):169-189. https://doi.org/10.1016/S0143-6228(98)00002-2

Kitasoo/Xai'xais. 2018. Kitasoo/Xai'xais management plan for Pacific Herring. Kitasoo/Xai'xais, Klemtu, British Columbia, Canada. [online] URL: https://klemtu.com/wp-content/uploads/2018/05/ KX-Herring-Mgmt-Plan-Jan-2018-final.pdf

Krapek, J., and B. Buma. 2015. Yellow-cedar: climate change and natural history at odds. Frontiers in Ecology and the Environment 13(5):280-281. https://doi.org/10.1890/1540-9295-13.5.280

Lambeck, R. J. 1997. Focal species: a multi-species umbrella for nature conservation. Conservation Biology 11(4):849-856. https:// doi.org/10.1046/j.1523-1739.1997.96319.X

Landres, P. B., J. Verner, and J. W. Thomas. 1988. Ecological uses of vertebrate indicator species: a critique. Conservation Biology 2 (4):316-328. https://doi.org/10.1111/j.1523-1739.1988.tb00195.X

Leonard, S., M. Parsons, K. Olawsky, and F. Kofod. 2013. The role of culture and traditional knowledge in climate change adaptation: insights from East Kimberley, Australia. Global Environmental Change 23(3):623-632. https://doi.org/10.1016/j. gloenvcha.2013.02.012
Lepofsky, D., C. G. Armstrong, S. Greening, J. Jackley, J. Carpenter, B. Guernsey, D. Mathews, and N. J. Turner. 2017. Historical ecology of cultural keystone places of the Northwest Coast. American Anthropologist 119(3):448-463. https://doi. org/10.1111/aman.12893

Lertzman, K., and A. Mackinnon. 2014. Why watersheds: evaluating the protection of undeveloped watersheds as a conservation strategy in northwestern North America. Pages 189-226 in G. Orians and J. Schoen, editors. North Pacific temperate rainforests: ecology and conservation. University of Washington Press, Seattle, Washington, USA

Levett, R. 1998. Sustainability indicators — integrating quality of life and environmental protection. Journal of the Royal Statistical Society: Series A (Statistics in Society) 161(3):291-302. https:// doi.org/10.1111/1467-985X.00109

Lindenmayer, D. B., C. R. Margules, and D. B. Botkin. 2000. Indicators of biodiversity for ecologically sustainable forest management. Conservation Biology 14(4):941-950. https://doi. org/10.1046/j.1523-1739.2000.98533.x

Mächler, E., K. Deiner, P. Steinmann, and F. Altermatt. 2014. Utility of environmental DNA for monitoring rare and indicator macroinvertebrate species. Freshwater Science 33(4):1174-1183. https://doi.org/10.1086/678128

Maffi, L. 2005. Linguistic, cultural, and biological diversity. Annual Review of Anthropology 34:599-617. https://doi. org/10.1146/annurev.anthro.34.081804.120437

Maffi, L., and E. Woodley. 2012. Biocultural diversity conservation: a global sourcebook. Routledge, London, UK. https://doi.org/10.4324/9781849774697

Martin, K., and J. M. Eadie. 1999. Nest webs: a community-wide approach to the management and conservation of cavity-nesting forest birds. Forest Ecology and Management 115(2-3):243-257. https://doi.org/10.1016/S0378-1127(98)00403-4

Mascarenhas, A., P. Coelho, E. Subtil, and T. B. Ramos. 2010. The role of common local indicators in regional sustainability assessment. Ecological Indicators 10(3):646-656. https://doi. org/10.1016/j.ecolind.2009.11.003

McCarter, J., E. J. Sterling, S. D. Jupiter, G. D. Cullman, S. Albert, M. Basi, E. Betley, D. Boseto, E. S. Bulehite, R. Harron, P. S. Holland, N. Horning, A. Hughes, N. Jino, C. Malone, S. Mauli, B. Pae, R. Papae, F. Rence, O. Revo, E. Taqala, M. Taqu, H. Woltz, and C. E. Filardi. 2018. Biocultural approaches to developing well-being indicators in Solomon Islands. Ecology and Society 23 (1):32. https://doi.org/10.5751/ES-09867-230132

McLain, R., M. Poe, K. Biedenweg, L. Cerveny, D. Besser, and D. Blahna. 2013. Making sense of human ecology mapping: an overview of approaches to integrating socio-spatial data into environmental planning. Human Ecology 41(5):651-665. https:// doi.org/10.1007/s10745-013-9573-0 Millennium Ecosystem Assessment. 2005. Ecosystems and human well-being. Island, Washington, D. C., USA.

Moller, H., F. Berkes, P. O. Lyver, and M. Kislalioglu. 2004. Combining science and traditional ecological knowledge: 
monitoring populations for co-management. Ecology and Society 9(3):2. https://doi.org/10.5751/ES-00675-090302

Moore, M. L., and O. Tjornbo. 2012. From coastal timber supply area to Great Bear Rainforest: exploring power in a socialecological governance innovation. Ecology and Society 17(4):26. https://doi.org/10.5751/ES-05194-170426

Nadasdy, P. 1999. The politics of TEK: power and the "integration" of knowledge. Arctic Anthropology: 36(9):1-18.

Nadasdy, P. 2003. Reevaluating the co-management success story. Arctic 56(4):367-380. https://doi.org/10.14430/arctic634

Niemi, G. J., and M. E. McDonald. 2004. Application of ecological indicators. Annual Review of Ecology, Evolution, and Systematics 35:89-111. https://doi.org/10.1146/annurev. ecolsys.35.112202.130132

Noss, R. F. 1990. Indicators for monitoring biodiversity: a hierarchical approach. Conservation Biology 4(4):355-364. https://doi.org/10.1111/j.1523-1739.1990.tb00309.x

Noss, R. F. 1999. Assessing and monitoring forest biodiversity: a suggested framework and indicators. Forest Ecology and Management 115(2-3):135-146. https://doi.org/10.1016/S0378-1127 (98)00394-6

Oakes, L. E. 2018. Ghosts and graveyards. Pages 19-30 in In Search of the canary tree: the story of a scientist, a cypress, and a changing world. Basic Books, New York, New York, USA.

Oakes, L. E., P. E. Hennon, N. M. Ardoin, D. V. D'Amore, A. J. Ferguson, E. A. Steel, D. T. Wittwer, and E. F. Lambin. 2015. Conservation in a social-ecological system experiencing climateinduced tree mortality. Biological Conservation. 192:276-285. https://doi.org/10.1016/j.biocon.2015.09.018

Oliver, J. 2007. Beyond the water's edge: towards a social archaeology of landscape on the Northwest Coast. Canadian Journal of Archaeology/Journal Canadien d'Archéologie 31 (1):1-27.

Östlund, L., O. Zackrisson, and G. Hörnberg, 2002. Trees on the border between nature and culture: culturally modified trees in boreal Sweden. Environmental History 7(1):48-68. https://doi. org/10.2307/3985452

Parliamentary Counsel Office, New Zealand Legislation. 2016. Te Awa Tupua (Whanganui River Claims Settlement) Bill 129-2. New Zealand Government, Wellington, New Zealand. [online] URL: http://www.legislation.govt.nz/bill/government/2016/0129/ latest/DLM6830851.html?src=qs

Price, M. H. H., C. T. Darimont, N. F. Temple, and S. M. MacDuffee. 2008. Ghost runs: management and status assessment of Pacific salmon (Oncorhynchus spp.) returning to British Columbia's central and north coasts. Canadian Journal of Fisheries and Aquatic Sciences 65(12):2712-2718. https://doi. org/10.1139/F08-174

Price, M. H. H., K. K. English, A. G. Rosenberger, M. MacDuffee, and J. D. Reynolds. 2017. Canada's wild salmon policy: an assessment of conservation progress in British Columbia. Canadian Journal of Fisheries and Aquatic Sciences 74 (10):1507-1518. https://doi.org/10.1139/cjfas-2017-0127
Price, K., A. Roburn, and A. MacKinnon. 2009. Ecosystem-based management in the Great Bear Rainforest. Forest Ecology and Management 258(4):495-503. https://doi.org/10.1016/j.foreco.2008.10.010

Pullin, A. S., W. Sutherland, T. Gardner, V. Kapos, and J. E. Fa. 2013. Conservation priorities: identifying need, taking action and evaluating success. Pages 3-22 in D. W. Macdonald and K. J. Willis, editors. Key Topics in Conservation Biology 2. Wiley-Blackwell, Chichester, West Sussex, UK. https://doi.org/10.1002/9781118520178. $\underline{\operatorname{ch} 1}$

Reed, M. S., E. D. G. Fraser, and A. J. Dougill. 2006. An adaptive learning process for developing and applying sustainability indicators with local communities. Ecological Economics 59 (4):406-418. https://doi.org/10.1016/j.ecolecon.2005.11.008

Roberge, J.-M., and P. Angelstam. 2004. Usefulness of the umbrella species concept as a conservation tool. Conservation Biology 18(1):76-85. https://doi.org/10.1111/j.1523-1739.2004.00450. $\underline{\mathrm{X}}$

Rogan, R., M. O'Connor, and P. Horwitz. 2005. Nowhere to hide: awareness and perceptions of environmental change, and their influence on relationships with place. Journal of Environmental Psychology 25(2):147-158. https://doi.org/10.1016/j.jenvp.2005.03.001

Salomon, A. K., K. B. J. Wilson, X. E. White, N. Tanape, Sr., and T. M. Happynook. 2015. First Nations perspectives on sea otter conservation in British Columbia and Alaska: insights into coupled human-ocean systems. Pages 301-331 in S. E. Larson, J. L. Bodkin, and G. R. VanBlaricom, editors. Sea otter conservation. Academic, Amsterdam, The Netherlands. https:// doi.org/10.1016/B978-0-12-801402-8.00011-1

Satterfield, T., R. Gregory, S. Klain, M. Roberts, and K. M. Chan. 2013. Culture, intangibles and metrics in environmental management. Journal of Environmental Management 117:103-114. https://doi.org/10.1016/j.jenvman.2012.11.033

Service, C. N., M. S. Adams, K. A. Artelle, P. Paquet, L. V. Grant, and C. T. Darimont. 2014. Indigenous knowledge and science unite to reveal spatial and temporal dimensions of distributional shift in wildlife of conservation concern. PLOS ONE 9(7): e101595. https://doi.org/10.1371/journal.pone.0101595

Siddig, A. A. H., A. M. Ellison, A. Ochs, C. Villar-Leeman, and M. K. Lau. 2016. How do ecologists select and use indicator species to monitor ecological change? Insights from 14 years of publication in Ecological Indicators. Ecological Indicators 60:223-230. https://doi.org/10.1016/j.ecolind.2015.06.036

Slocombe, D. S. 1993. Implementing ecosystem-based management: development of theory, practice, and research for planning and managing a region. BioScience 43(9):612-622. https://doi.org/10.2307/1312148

Slocombe, D. S. 1998. Defining goals and criteria for ecosystembased management. Environmental Management 22(4):483-493. https://doi.org/10.1007/s002679900121

Stedman, R. C. 2003. Is it really just a social construction? The contribution of the physical environment to sense of place. Society \& Natural Resources: An International Journal 16 (8):671-685. https://doi.org/10.1080/08941920309189 
Sterling, E. J., C. Filardi, A. Toomey, A. Sigouin, E. Betley, N. Gazit, J. Newell, S. Albert, D. Alvira, N. Bergamini, M. Blair, D. Boseto, K. Burrows, N. Bynum, S. Caillon, J. E. Caselle, J. Claudet, G. Cullman, R. Dacks, P. B. Eyzaguirre, S. Gray, J. Herrera, P. Kenilorea, K. Kinney, N. Kurashima, S. Macey, C. Malone, S. Mauli, J. McCarter, H. McMillen, P. Pascua, P. Pikacha, A. L. Porzecanski, P. de Robert, M. Salpeteur, M. Sirikolo, M. H. Stege, K. Stege, T. Ticktin, R. Vave, A. Wali, P. West, K. B. Winter, and S. D. Jupiter. 2017a. Biocultural approaches to well-being and sustainability indicators across scales. Nature Ecology \& Evolution 1(12):1798-1806. https://doi.org/10.1038/s41559-017-0349-6

Sterling, E., T. Ticktin, T. K. K. Morgan, G. Cullman, D. Alvira, P. Andrade, N. Bergamini, E. Betley, K. Burrows, S. Caillon, J. Claudet, R. Dacks, P. Eyzaguirre, C. Filardi, N. Gazit, C. Giardina, S. Jupiter, K. Kinney, J. McCarter, M. Mejia, K. Morishige, J. Newell, L. Noori, J. Parks, P. Pascua, A. Ravikumar, J. Tanguay, A. Sigouin, T. Stege, M. Stege, and A. Wali. $2017 b$. Culturally grounded indicators of resilience in social-ecological systems. Environment and Society: Advances in Research 8 (1):63-95. https://doi.org/10.3167/ares.2017.080104

Sutherland, I. J., S. E. Gergel, and E. M. Bennett. 2016. Seeing the forest for its multiple ecosystem services: indicators for cultural services in heterogeneous forests. Ecological Indicators 71:123-133. https://doi.org/10.1016/j.ecolind.2016.06.037

Sutherland, W. J., A. S. Pullin, P. M. Dolman, and T. M. Knight. 2004. The need for evidence-based conservation. Trends in Ecology \& Evolution 19(6):305-308. https://doi.org/10.1016/j. tree.2004.03.018

Takeda, L., and I. Røpke. 2010. Power and contestation in collaborative ecosystem-based management: the case of Haida Gwaii. Ecological Economics 70(2):178-188. https://doi. org/10.1016/j.ecolecon.2010.02.007

Tallis, H., P. S. Levin, M. Ruckelshaus, S. E. Lester, K. L. McLeod, D. L. Fluharty, and B. S. Halpern. 2010. The many faces of ecosystem-based management: making the process work today in real places. Marine Policy 34(2):340-348. https://doi.org/10.1016/ j.marpol.2009.08.003

Trant, A. J., W. Nijland, K. M. Hoffman, D. L. Mathews, D. McLaren, T. A. Nelson, and B. M. Starzomski, 2016. Intertidal resource use over millennia enhances forest productivity. Nature Communications. 7:12491. https://doi.org/10.1038/ncomms12491

Trosper, R. L. 2002. Northwest Coast Indigenous institutions that supported resilience and sustainability. Ecological Economics 41 (2):329-344. https://doi.org/10.1016/S0921-8009(02)00041-1

Turner, N. J., Y. Ari, F. Berkes, I. Davidson-Hunt, Z. F. Ertug, and A. Miller. 2009. Cultural management of living trees: an international perspective. Journal of Ethnobiology 29(2):237-270. https://doi.org/10.2993/0278-0771-29.2.237

Turner, N. J., F. Berkes, J. Stephenson, and J. Dick. 2013. Blundering intruders: extraneous impacts on two Indigenous food systems. Human Ecology 41(4):563-574. https://doi. org/10.1007/s10745-013-9591-y

Turner, N. J., R. Gregory, C. Brooks, L. Failing, and T. Satterfield. 2008. From invisibility to transparency: identifying the implications. Ecology and Society 13(2):7. https://doi. org/10.5751/es-02405-130207

United Nations Educational, Scientific, and Cultural Organization (UNESCO). 2003. Convention for the safeguarding of the intangible cultural heritage. UNESCO, Paris, France. [online] URL: http://orcp.hustoj.com/wp-content/uploads/2016/03/ Convention-for-the-Safe2003.pdf

Waller, D., and N. J. Reo. 2018. First stewards: ecological outcomes of forest and wildlife stewardship by Indigenous peoples of Wisconsin, USA. Ecology and Society 23(1):45. https:// doi.org/10.5751/ES-09865-230145

Williams, D. R., and S. I. Stewart. 1998. Sense of place: an elusive concept that is finding a home in ecosystem management. Journal of Forestry 96(5):18-23. 